\title{
KONDISI MENTAL WASIT MEMIMPIN PERTANDINGAN SEMIFINAL LIGA REMAJA BOLA VOLI PROVINSI JAWA TIMUR TAHUN 2020
}

\author{
Noer Wachid Riqzal Firdauz', Mohammad Hasan Basri² \\ 1,2,STKIP PGRI Sumenep \\ E-mail: riqzal@stkippgrisumenep.ac.id¹, moh_hasan_basri@stkippgrisumenep.ac.id² \\ DOI: https://doi.org/10.36526/kejaora.v5i2.1062
}

\begin{abstract}
ABSTRAK
Mental wasit sangat berpengaruh untuk memimpin setiap pertandingan. Sebab apabila seorang wasit memiliki mental yang baik, maka akan berpengaruh terhadap kinerja dan produktivitasnya. Penelitian ini bertujuan untuk mengetahui kondisi mental wasit memimpin pertandingan semifinal liga remaja bolavoli Provinsi Jawa Timur tahun 2020. Metode yang digunakan dalam penelitian ini adalah kuantitatif deskriptif. Sampel penelitian berjumlah 8 orag wasit. Dalam penelitian ini teknik analisis data yang digunaka adalah deskriptif sederhana. Hasil penelitian ini menunjukkan bahwa kondisi mental wasit sangat dipengaruhi oleh beberapa faktor yaitu kelelahan, suasana amarah, perasaan siap, energik dan penuh tenaga, ketegangan, penilaian diri, suasana bingung dan depresi. Semakin besar skor pada faktor kelelahan, suasana amarah, ketegangan, suasana bingung dan depresi semakin rendah kondisi mentalnya. Sedangkan untuk faktor perasaan siap, energik, dan penuh tenaga dan penilaian diri semakin besar faktornya semakin tinggi pula kondisi mentalnya.. HA dan NW mempunyai kondisi mental yang baik diantara wasit-wasit yang lain saat memimpin pertandingan semifinal liga remaja bolavoli Provnsi Jawa Timur tahun 2020. Dari penelitian ini dapat disimpulkan kondisi mental wasit yang memimpin pertandingan semifinal liga remaja bolavoli Provinsi Jawa Timur tahun 2020 rata-rata dalam keadaan baik.
\end{abstract}

\section{Kata Kunci: Kondisi Mental Wasit, Pertandingan Semifinal}

\section{PENDAHULUAN}

Dalam suatu pertandingan harus ada salah seorang yang bertindak sebagai pengadil. Dalam kegiatan olahraga kita sering menyebutnya wasit. Seorang wasit yang baik, akan membantu peningkatan prestasi. Sebab penafsiran keadaan dan penafsiran peraturan permainan dari wasit itu akan selalu tepat dan benar. Ketepatan dan kebenaran penafsiran akan menunjang kepada perkembangan teknik maupun taktik bagi cabang olahraga tersebut.

Seorang wasit harus bisa bersifat netral dan adil pada tim yang bertanding. Selan itu wasit juga ikut harus menjunjung tinggi sportivitas dalam pertandingan. Wasit yang baik adalah wasit yang yakin dengan keputusannya yang didasari oleh peraturan permainan, tidak mudah terpengaruh oleh intervensi dari pihak lain dan selalu memegang teguh kode etik wasit.

Selain pemahaman tentang peraturan permainan wasit juga membutuhkan tingkat kebugaran dan psikologi yang baik. Dengan olahraga dan aktivitas jasmani yang dilakukan hingga intensitas memadai sangat efektif sebagai tempat untuk meningkatkan ketahanan tubuh terhadap stress dan menanggulangi depresi, karena dalam melakukan aktivitas jasmani diharapkan selalu tercipta suasana gembira (Santoso, 2016). Dimana suasana gembira dapat membantu wasit menurunkan tingkat stres saat memimpin pertandingan.

Kecemasan merupakan masalah gejolak emosi yang sering menghadapi atlet (Setiabudi \& Santoso, 2020). Begitu juga seorang wasit dalam memimpin pertandingan semifinal dengan dinamika yang tinggi daripada pertandingan-pertandingan di babak penyisihan. Pada pertandingan semifinal yang bertanding adalah tim-tim yang sudah pernah mengalahkan tim lain di babak penyisihan, oleh sebab itu suasana pertandingan akan lebih seru dan mereka lebih berkeinginan menjadi pemenang. Pada 
situasi seperti ini wasit sangat dibutuhkan dalam mengambil keputusan pertandingan. Pada kondisi ini tingkat kecemasan wasit sangat berlebihan, hal ini bisa diatasi dengan pendekatan teknik imagery positif (Effendi, 2017).

Kondisi pertandingan dengan tensi tinggi juga akan mempengaruhi psikis seorang wasit secara langsung, ketegangan emosi yang berlebihan sehingga mempengaruhi seluruh penampilan dalam mengambil keputusan (Effendi, 2016).

Khusus berkenaan dengan perwasitan peningkatan kualitas wasit selalu dilakukan baik dalam memahami aturan permainan, kejelian dan yang paling penting adalah mental dalam memimpin pertandingan. Membentuk mental adalah kualitas yang harus dimiliki oleh seorang wasit, karena yang membedakan wasit luar biasa dan wasit berkemampuan rata- rata adalah sikap mental. Sikap mental itu sendiri adalah gabungan dari keyakinan, pengetahuan peraturan pertandingan, pengendalian diri, dan komunikasi.

Pembinaan mental wasit disamping dilakukan untuk menyikapi mental wasit sebelum memimpin pertandingan, juga ditujukan untuk membina ketahanan mental. Ketahanan mental adalah kondisi kejiwaan yang mengandung kesanggupan untuk mengembangkan kemampuan menghadapi gangguan ancaman dalam keadaan bagaimanapun juga, baik yang datang dari dirinya sendiri maupun dari luar dirinya. Hal ini perlu dilatih dengan memenuhi aspek akal, aspek kemauan, dan aspek emosional (Kiswantoro, 2016).

Dari uraian di atas dapat kita simpulkan bahwa mental wasit sangat berpengaruh untuk memimpin setiap pertandingan. Sebab apabila seorang wasit memiliki mental yang baik, maka akan berpengaruh terhadap kinerja dan produktivitasnya. Maka tidak heran apabila tes psikologis sangat dibutuhkan untuk menilai seorang wasit layak untuk memimpin pertandingan atau tidak. Dalam hal ini kondisi mental digambarkan dengan menilai profil mood wasit itu sendiri.

Kondisi mental seorang wasit sangat diperlukan dalam memimpin pertandingan dalam segala event, baik event regional, nasional maupun internasional. Wasit juga tetap harus mempersiapkan mental untuk memimpin pertandingan baik antar pemain profesional, pemain senior, pemain junior, maupun pemain remaja.

Tidak seperti memimpin pertandingan tingkat senior atau junior, memimpin pertandingan antar remaja lebih mudah. Hal ini dikarenakan pertandingan antar remaja masih belum banyak terjadi kesalahankesalahan yang fatal dari para pemain. Akan tetapi, dinamika pertandingan pada saat laga semifinal dan final akan meningkat. Sehingga peran wasit akan lebih diperlukan pada pertandingan semifinal dan final. Oleh sebab itu, penulis tertarik untuk melakukan penelitian tentang Kondisi Mental Wasit Saat Memimpin Pertandingan Semifinal Dan Final Liga Remaja Bolavoli Propinsi Jawa Timur Tahun 2020.

\section{METODE}

Penelitian ini merupakan jenis penelitian deskriptif kuantitatif dengan menggunakan studi angket/kuesioner (Maksum, 2012).

Sedangkan apabila dilihat dari kedalaman analisisnya, jenis penelitian ini termasuk penelitian deskriptif. Penelitian deskriptif adalah membuat pemerian (penyandaraan) secara sistematis, faktual dan akurat mengenani fakta-fakta dan sifatsifat populasi tertentu (Arikunto, 2006).

\section{HASIL DAN PEMBAHASAN}

Tabel 1. Analisis Sampel 1

\begin{tabular}{llll}
\hline \multirow{2}{*}{ No } & \multicolumn{1}{c}{ Faktor } & \multicolumn{2}{c}{ Semifinal } \\
\cline { 2 - 4 } & Kelelahan & 0 & 0 \\
\hline 1 & Skor & $\%$ \\
\hline 2 & $\begin{array}{l}\text { Suasana } \\
\text { Amarah }\end{array}$ & 0 & 0 \\
\hline \multirow{2}{*}{$\begin{array}{l}\text { Perasaan siap, } \\
\text { energik } \\
\text { dan penuh } \\
\text { tenaga }\end{array}$} & 23 & 65,7 \\
\hline 4 & Ketegangan & 4 & 14,3 \\
\hline 5 & Penilaian diri & 11 & 39,3 \\
\hline 6 & $\begin{array}{l}\text { Suasana } \\
\text { bingung }\end{array}$ & 7 & 25 \\
\hline 7 & Depresi & 0 & 0 \\
\hline
\end{tabular}


Dari tabel $1 \mathrm{di}$ atas, dapat kita lihat bahwa beberapa indikator seperti kelelahan, suasana amarah dan depresi tidak mempengaruhi kondisi mental dan penampilan. Hal ini ditunjukkan dengan skor di masing-masing indikator adalah 0 . Untuk perasaan siap, energik dan penuh tenaga saat memimpin pertandingan semifinal pertama putra menunjukkan skor 23 dengan prosentase $65,7 \%$. Hal ini menunjukkan bahwa siap untuk memimpin pertandingan semifinal. Ketegangan pada saat pertandingan semifinal pertama putra hanya $14,3 \%$. Penilaian diri saat semifinal ditunjukkan dengan skor $39,3 \%$. Suasana bingung menunjukkan skor 25\%. Dapat disimpulkan bahwa kondisi mental sangat baik, karena semua indikator menunjukkan tingkatan yang rendah dan tingkatan tinggi ditunjukkan pada indikator perasaan siap, energik dan penuh tenaga.

Tabel 2. Analisis Sampel 2

\begin{tabular}{ll|l|l}
\hline \multirow{2}{*}{ No } & \multirow{2}{*}{ Faktor } & \multicolumn{2}{l}{ Semifinal } \\
\cline { 3 - 4 } & Skor & $\%$ \\
\hline 1 & Kelelahan & 3 & 10,7 \\
\hline 2 & Suasana Amarah & 2 & 7,1 \\
\hline \multirow{3}{3}{3} & $\begin{array}{l}\text { Perasaan siap, } \\
\text { energik } \\
\text { dan penuh tenaga }\end{array}$ & 11 & 31,4 \\
\hline 4 & Ketegangan & 5 & 17,8 \\
\hline 5 & Penilaian diri & 8 & 28,6 \\
\hline 6 & Suasana bingung & 6 & 21,4 \\
\hline 7 & Depresi & 1 & 3,5 \\
\hline
\end{tabular}

Dari tabel 2 di atas, dapat dijabarkan berdasarkan indikator-indikator yang mempengaruhi kondisi mental. Kelelahan saat semifinal pertama putra ditunjukkan dengan skor $3(10,7 \%)$. Berbeda dengan kelelahan, suasana amarah ditumjukkam dengan skor 2 (7,1\%). Untuk indikator perasaan siap, energik dan penuh tenaga ditunjukkan dengan skor $11(31,4 \%)$, indikator penilaian diri ditunjukkan dengan skor 8 $(28,6 \%)$. Sampel bisa mengatasi ketegangannya dengan baik saat pertandingan semifinal yang ditunjukkan dengan skor $5(17,8 \%)$. Suasana bingung menunjukkan skor $6(21,4 \%)$ pada saat semifinal. Pada indikator depresi, menunjukkan skor yang baik yaitu, tingkat depresi saat menjadi wasit kedua semifinal pertama putra yang ditunjukkan dengan skor $1(3,5 \%)$.

Secara garis besar dapat disimpulkan bahwa kondisi mental masih belum stabil. Karena ada beberapa indikator yang rendah tetapi ada beberapa indikator juga yang tinggi.

Tabel 3. Analisis Sampel 3

\begin{tabular}{ll|l|l|}
\hline \multirow{2}{*}{ No } & \multirow{2}{*}{ Faktor } & \multicolumn{2}{l}{ Semifinal } \\
\cline { 3 - 4 } & Skor & \multicolumn{1}{l}{$\%$} \\
\hline 1 & Kelelahan & 3 & 10,7 \\
\hline 2 & Suasana Amarah & 2 & 7,1 \\
\hline \multirow{2}{*}{3} & $\begin{array}{l}\text { Perasaan siap, } \\
\text { energik } \\
\text { dan penuh tenaga }\end{array}$ & 15 & 42,8 \\
\hline 4 & Ketegangan & 13 & 46,4 \\
\hline 5 & Penilaian diri & 12 & 42,8 \\
\hline 6 & Suasana bingung & 8 & 28,6 \\
\hline 7 & Depresi & 1 & 3,5 \\
\hline
\end{tabular}

Dari tabel 3 di atas, dapat kita lihat tingkat kelelahan saat memimpin pertandingan semifinal pertama putri menunjukkan skor $3(10,7 \%)$. Akan tetapi berbeda dengan kelelahan, suasana amarah yang dirasakan baik saat semifinal yaitu dengan skor $2(7,1 \%)$. Perasaan siap, energik dan penuh semangat subyek mempunyai skor saat semifinal yaitu $15(42,8 \%)$. Tapi hal yang tidak baik adalah tingkat ketegangan yang pada saat semifinal tinggi, ini terlihat dari skor $13(46,4 \%)$ pada saat memimpin pertandingan semifinal pertama putri. Dalam hal penilaian diri, menunjukkan skor 12 $(42,8 \%)$. Pada indikator suasana bingung saat semifinal ditunjukkan dengan skor 8 $(28,6 \%)$. Pada indikator depresi menunjukkan skor $1(3,5 \%)$ saat memimpin pertandingan semifinal pertama putri. Dapat disimpulkan secara umum bahwa kondisi mental masih belum stabil juga saat memimpin pertandingan semifinal.

Tabel 4. Analisis Sampel 4

\begin{tabular}{ll|l|l|}
\hline \multirow{2}{*}{ No } & \multirow{2}{*}{ Faktor } & \multicolumn{2}{l}{ Semifinal } \\
\cline { 3 - 4 } & Kkor & $\%$ \\
\hline 1 & Kelelahan & 6 & 21,4 \\
\hline 2 & Suasana Amarah & 0 & 0 \\
\hline 3 & $\begin{array}{l}\text { Perasaan siap, } \\
\text { energik } \\
\text { dan penuh tenaga }\end{array}$ & 20 & 57,1 \\
\hline
\end{tabular}




\begin{tabular}{ll|l|l|}
\hline 4 & Ketegangan & 7 & 25 \\
\hline 5 & Penilaian diri & 15 & 53,6 \\
\hline 6 & Suasana bingung & 4 & 14,3 \\
\hline 7 & Depresi & 3 & 10,7 \\
\hline
\end{tabular}

Dari data di dalam tabel 4, kelelahanan menunjukkan skor $6(21,4 \%)$. Berarti Suasana amarah tidak dirasakan oleh saat semifinal karena skor yang ditunjukkan adalah 0 . Berbalik dari perasaan siap,energik dan penuh tenaga saat semifinal ditunjukkan dengan skor $20(57,1 \%)$. Untuk indikator ketegangan ditunjukkan skor 7 (25\%). Penilaian diri tetap dalam tingkatan tinggi yaitu $15(53,6 \%)$. Suasanan bingung yang dirasakan oleh ditunjukkan dengan skor 4 $(14,3 \%)$. Indikator ditunjukkan dengan skor 3 $(10,7 \%)$.

Secara umum dapat kita simpulkan bahwa kondisi mental tidak stabil dalam memimpin pertandingan semifinal. Hal ini dapat kita lihat dari skor yang tinggi di setiap indikator yang mempengaruhi kondisi mental.

Tabel 5. Analisis Sampel 5

\begin{tabular}{ll|l|l}
\hline \multirow{2}{*}{ No } & \multirow{2}{*}{ Faktor } & \multicolumn{2}{l}{ Semifinal } \\
\cline { 3 - 4 } & Skor & $\%$ \\
\hline 1 & Kelelahan & 0 & 0 \\
\hline 2 & Suasana Amarah & 0 & 0 \\
\hline \multirow{3}{*}{3} & $\begin{array}{l}\text { Perasaan siap, } \\
\text { energik } \\
\text { dan penuh tenaga }\end{array}$ & 18 & 51,4 \\
\hline 4 & Ketegangan & 4 & 14,3 \\
\hline 5 & Penilaian diri & 14 & 50 \\
\hline 6 & Suasana bingung & 4 & 14,3 \\
\hline 7 & Depresi & 0 & 0 \\
\hline
\end{tabular}

Dapat dilihat pada tabel di atas, bahwa faktor kelelahan tidak mempengaruhi kondisi mental karena skor indikator kelelahan menunjukkan angka 0 . Suasana amarah pada saat memimpin pertandingan semifinal kedua putra menunjukkan skor 0. Sampel memiliki skor perasaan siap, energik dan penuh semangat baik saat memimpin semifinal yang ditunjukkan dengan skor 18 $(51,4 \%)$. Ketegangan yang dirasakan pada saat semifinal adalah $4(14,3 \%)$. Penilaian diri juga baik saat semifinal yang ditunjukkan dengan skor 14 (50\%). Pada indikator suasana bingung, menunjukkan skor 4 $(14,3 \%)$. Depresi tidak dirasakan saat memimpin pertandingan semifinal kedua putra yang ditunjukkan dengan skor 0 .

Dapat kita simpulkan secara umum bahwa kondisi mental saat memimpin semifinal kedua putra baik. Bisa kita lihat dari skor masing-masing indikator. Kelelahan, suasana amarah, ketegangan, suasana bingung, depresi yang rendah dan perasaan siap, energik dan penuh tenaga, penilaian diri yang tinggi.

Tabel 6. Analisis Sampel 6

\begin{tabular}{ll|l|l|}
\hline \multirow{2}{*}{ No } & \multirow{2}{*}{ Faktor } & \multicolumn{2}{l}{ Semifinal } \\
\cline { 3 - 4 } & Skor & $\%$ \\
\hline 1 & Kelelahan & 2 & 7,1 \\
\hline 2 & Suasana Amarah & 2 & 7,1 \\
\hline 3 & $\begin{array}{l}\text { Perasaan siap, } \\
\text { energik } \\
\text { dan penuh tenaga }\end{array}$ & 11 & 31,4 \\
\hline 4 & Ketegangan & 8 & 28,6 \\
\hline 5 & Penilaian diri & 10 & 35,7 \\
\hline 6 & Suasana bingung & 2 & 7,1 \\
\hline 7 & Depresi & 6 & 21,4 \\
\hline
\end{tabular}

Dari tabel 6 di atas, pada faktor kelelahan merasakan kelelahan yang ditunjukkan dengan skor $2(7,1 \%)$ saat menjadi wasit kedua semifinal kedua putra. Untuk suasana amarah, menunjukkan skor 2 $(7,1 \%)$. Untuk perasaan siap, energik dan penuh tenaga menunjukkan skor $11(31,4 \%)$. Ketegangan saat semifinal menunjukkan skor 8 (28,6\%). Indikator penilaian diri menunjukkan skor 10 (35, 7\%). Suasana bingung menunjukkan skor $2(7,1 \%)$. Dan depresi yang dirasakan menunjukkan skor 6 $(21,4 \%)$. Secara garis besar kondisi mental lebih cukup baik pada saat bertugas menjadi wasit kedua pertandingan semifinal kedua putra.

Tabel 7. Analisis Sampel 7

\begin{tabular}{ll|l|l}
\hline \multirow{2}{*}{ No } & \multirow{2}{*}{ Faktor } & \multicolumn{2}{l}{ Semifinal } \\
\cline { 3 - 4 } & Skor & $\%$ \\
\hline 1 & Kelelahan & 2 & 7,1 \\
\hline 2 & Suasana Amarah & 1 & 3,6 \\
\hline \multirow{2}{*}{3} & $\begin{array}{l}\text { Perasaan siap, } \\
\text { energik } \\
\text { dan penuh tenaga }\end{array}$ & 8 & 22,8 \\
\hline 4 & Ketegangan & 6 & 21,4 \\
\hline 5 & Penilaian diri & 5 & 17,8 \\
\hline 6 & Suasana bingung & 5 & 17,8 \\
\hline 7 & Depresi & 3 & 10,7 \\
\hline
\end{tabular}


Dari tabel 7 di atas dapat dijabarkan bahwa ketegangan saat memimpin pertandingan semifinal kedua putri menunjukkan skor $2(7,1 \%)$. Suasana amarah pada saat semifinal adalah $1(3,6 \%)$. Perasaan siap, energik dan penuh tenaga berada pada $8(22,8 \%)$ saat memimpin pertandingan semifinal kedua putri. Ketegangan pada semifinal menunjukkan tingkatan skor $6(21,4 \%)$. Untuk indikator penilaian diri menunjukan skor $5(17,8 \%)$. Suasana bingung menunjukkan skor 5 $(17,8 \%)$ dan depresi menunjukkan skor 3 $(10,7 \%)$. Secara umum kondisi mental pada saat memimpin pertandingan semifinal kedua putri masih kurang.

Tabel 8. Analisis Sampel 8

\begin{tabular}{ll|l|l}
\hline \multirow{2}{*}{ No } & \multirow{2}{*}{ Faktor } & \multicolumn{2}{l}{ Semifinal } \\
\cline { 3 - 4 } & Skor & $\%$ \\
\hline 1 & Kelelahan & 1 & 3,6 \\
\hline 2 & Suasana Amarah & 2 & 7,1 \\
\hline 3 & $\begin{array}{l}\text { Perasaan siap, } \\
\text { energik } \\
\text { dan penuh tenaga }\end{array}$ & 13 & 37,1 \\
\hline 4 & Ketegangan & 10 & 35,7 \\
\hline 5 & Penilaian diri & 11 & 39,3 \\
\hline 6 & Suasana bingung & 6 & 21,4 \\
\hline 7 & Depresi & 2 & 7,1 \\
\hline
\end{tabular}

Dari data tabel 8 di atas, dapat kita lihat bahwa tingkat kelelahan memimpin pertandingan semifinal menunjukkan skor 1 $(3,6 \%)$. Suasana amarah menunjukkan skor 2 $(7,1 \%)$. Untuk perasaan siap, energik dan penuh tenaga, menunjukkan skor $13(37,1 \%)$. Ketegangan saat memimpin pertandingan semifinal menunjukkan skor 10 (35,7\%). Sebaliknya, untuk aspek penilaian diri pada pertandingan semifinal menunjukkan skor 11 $(39,3 \%)$. Pada suasana bingung menunjukkan skor $6(21,4 \%)$. Pada indikator depresi menunjukkan skor $2(7,1 \%)$. Bisa dijelaskan secara garis besar bahwa kondisi mental masih kurang saat memimpin semifinal.

Dari penjelasan di atas dapat disimpulkan, bahwa kondisi mental wasit yang memimpin pertandingan semifinal liga remaja bolavoli Provinsi Jawa Timur tahun 2020 dalam keadaan cukup baik.
Untuk memiliki kondisi mental yang baik wasit harus mengurangi tingkat kelelahan, suasana amarah, ketegangan, suasana bingung dan depresi dengan berbagai cara. Semakin mampu seorang untuk bersikap positif terhadap tekanan maka semakin rendah kecemasannya menghadapi kompetisi (Algani et al., 2018). Salah satunya olahraga yang teratur dan menjaga kebugaran agar tidak mudah lelah sehingga tidak menyebabkan menurunnya indikatorindikator yang lain. Latihan mental sama pentingnya dengan latihan fisik. Latihan mental dapat dilakukan dengan latihan relaksasi. Relaksasi adalah suatu keadaan dimana tidak terdapat ketegangan baik secara fisik, emosi maupun mental. Untuk menampilkan performa yang baik dalam memimpin pertandingan diperlukan keadaan fisik dan mental yang relaks. Dengan otot-otot yang rileks dapat ditampilkan gerakan yang benar serta akan mendapatkan kecepatan dan ketepatan berpikir dalam mengambil keputusan. Latihan relaksasi dapat dilakukan sekitar 10 sampe 15 menit setiap hari atau saat diperlukan. Seperti senam Tai Chi dengan rutin baik sebelum maupun sesudah menginjak usia lanjut memiliki kesehatan mental emosional yang baik sebagai penunjang kesehatan tubuh secara keseluruhan (Priana, 2017).

Sedangkan untuk indikator perasaan siap, energik dan penuh tenaga dan penilaian diri dapat ditingkatkan dengan cara latihan visualisasi. Visualisasi dimaksudkan sebagai melihat gerakan diri sendiri di dalam pikiran. Gerakan yang divisualisasikan, yang terlihat di dalam pikiran, secara sadar dikendalikan oleh orang yang melakukan visualisasi tersebut. Latihan visualisasi ini harus dilakukan secara teratur dan berulang- ulang, misalnya pada malam hari sebelum tidur. Memvisualisasikan pertandingan yang sudah dipimpinnya akan meningkatkan indikator penilaian diri, sedangkan memvisualisasikan pertandingan yang akan dipimpin esok hari akan meningkatkan perasaan siap, energik dan penuh tenaga. Hal ini sesuai dengan hasil penelitian degan latihan mental imagery dapat menigkatkan rasa percaya diri (Wibowo \& Rahayu, 2016) 


\section{KESIMPULAN}

Berdasarkan hasil penelitian dan pembahasan yang telah diuraikan di atas, maka dapat disimpulkan bahwa setiap subjek memiliki kondisi mental yang berbeda-beda dalam memimpin pertandingan semifinal liga remaja bolavoli Provinsi Jawa Timur tahun 2020. Kondisi mental wasit yang memimpin pertandingan semifinal liga remaja bolavoli Provinsi Jawa Timur tahun 2020 dalam keadaan cukup baik.

Untuk memiliki kondisi mental yang baik wasit harus mengurangi tingkat kelelahan, suasana amarah, ketegangan, suasana bingung dan depresi dengan cara olahraga yang teratur dan menjaga kebugaran agar tidak mudah lelah sehingga tidak menyebabkan menurunnya indikatorindikator yang lain. Untuk indikator perasaan siap, energik dan penuh tenaga dan penilaian diri dapat ditingkatkan dengan cara latihan visualisasi.

Bagi peneliti selanjutnya, dapat dijadikan bahan masukan dan perbandingan dan mengembangkan penelitian ke yang lebih luas.

\section{DAFTAR PUSTAKA}

Algani, P. W., Yuniardi, M. S., \& Masturah, A. N. (2018). Mental Toughness dan Competitive Anxiety pada Atlet Bola Voli. Jurnal IImiah Psikologi Terapan, 06(01), 93-101.

Arikunto, S. (2006). Prosedur Penelitian, Edisi Revisi VI. Jakarta: PT. Rineka Cipta.

Effendi, H. (2016). Peranan psikologi olahraga dalam meningkatkan prestasi atlet. Nusantara (Jurnal IImu Pengetahuan Sosial), 1, 23-30.

Effendi, H. (2017). Mengatasi Kecemasan Pada Atlet Sebelum Pertandingan Melalui Pendekatan Kognitif. Jurnal Menssana, 2(1), 37-44.

Kiswantoro, A. (2016). Pembinaan Mental Bagi Atlet Pemula Untuk Membantu Pengendalian Agresifitas. Jurnal Konseling Gusjigang, 2(1), 81-89. https://doi.org/10.24176/jkg.v2i1.560

Maksum, A. (2012). Metodologi Penelitihan Dalam Olahraga. Surabaya: Universitas Negeri Surabaya University Press.
Priana, A. (2017). Pengaruh Olahraga Senam Tai Chi terhadap Kesehatan Mental Emosional Lanjut Usia (Studi Kasus pada Komunitas Senam Tai Chi Lanjut Usia Kota Tasikmalaya). Universitas Siliwangi, 1(1), 32-39.

Santoso, D. A. (2016). Analisis Tingkat Kebugaran Jasmani Atlet Bolavoli Putri Universitas Pgri Banyuwangi. Kejaora, 1(1), 37-46.

Setiabudi, M. A., \& Santoso, D. A. (2020). Tingkat Kecemasan (Anxiety) Dalam Olahraga Berbasis Perbedaan Etnis (Suku Osing, Jawa, Dan Madura). Jurnal Altius: Jurnal Ilmu Olahraga Dan Kesehatan, 9(1), 1-8.

Wibowo, S. A. P., \& Rahayu, N. I. (2016). Pengaruh Latihan Mental Imagery Terhadap Hasil Tembakan Atlet Menembak Rifle Jawa Barat. Jurnal Terapan IImu Keolahragaan, 1(2), 23. https://doi.org/10.17509/jikor.v1i2.277 6 